\title{
Health Physics Enrollments and Degrees Survey, 2006 Data
}

\section{SURVEY UNIVERSE}

The survey includes degrees granted between September 1, 2005 and August 31, 2006. Enrollment information refers to the fall term 2006. Thirty academic programs were included in the survey universe and all 30 responded. Two programs were discontinued and deleted from the survey after 2005, and one new program was added in the 2006 survey. The report includes data by degree level for post-graduation plans and enrollment information on undergraduate students and graduate students.

\section{DEGREE DATA}

Bachelor's Degrees. The number of B.S. degrees granted in 2006 by health physics, medical health physics, and other health physics option programs decreased by $9 \%$ from 2005 , but was still well above the number of B.S. degrees reported between 1996 and 2004. (See Table 1.) Health physics programs accounted for $90 \%$ of all B.S. degrees. (See Table 2.)

Graduate Degrees. In 2006 compared to 2005, the number of master's degrees granted increased by $17 \%$, and the number of doctorate degrees granted decreased slightly. (See Table 1.) The number of master's degrees granted was the largest since 1999. The number of doctorate degrees remained at the lowest level reported since the survey began in the mid 1970s. Health physics programs accounted for $83 \%$ of the master's degrees and $75 \%$ of the doctorate degrees. (See Table 2.)

Table 1. Health Physics Degrees, 1998-2006

\begin{tabular}{cccc} 
& \multicolumn{3}{c}{ Degrees } \\
\cline { 2 - 4 } Year & B.S. & M.S. & Ph.D. \\
\hline 2006 & 71 & 90 & 12 \\
2005 & 78 & 77 & 14 \\
2004 & 54 & 64 & 14 \\
2003 & 56 & 73 & 25 \\
2002 & 41 & 76 & 20 \\
2001 & 37 & 71 & 23 \\
2000 & 33 & 79 & 24 \\
1999 & 55 & 115 & 22 \\
1998 & 51 & 118 & 26
\end{tabular}

The data reflect the 2002 update of the survey universe of health physics programs.

Table 2. Health Physics Degrees by Curriculum, 2006

\begin{tabular}{lrrc}
\multicolumn{1}{c}{ Curriculum } & B.S. & M.S. & Ph.D. \\
\hline Health Physics Program & 64 & 75 & 9 \\
Medical Health Physics & 0 & 15 & 3 \\
Other Health Physics Option & 7 & 0 & 0
\end{tabular}




\section{ENROLLMENTS AND SHORT-TERM OUTLOOK FOR DEGREE TRENDS}

Undergraduate Students. In 2006, the reported enrollment of undergraduate students increased for the fourth consecutive year, but was less than 5\% higher than enrollment reported in 2005 . The 2005 and 2006 undergraduate enrollment levels are approximately triple the enrollment level in 2000 . The continuing increases in undergraduate enrollments have generated increases in the number of B.S. degrees in the last two years, and indicate that the number of B.S. degrees is likely to continue to increase at least for the next couple of years.

Graduate Students. In 2006, the reported enrollment of graduate students also increased for the fourth consecutive year, but was less than $2 \%$ higher than reported graduate enrollments in 2005 . The continuing increases in graduate enrollment have resulted in the increase in M.S. degrees granted in the last two years, and indicate that the number of M.S. degrees should continue to increase for the next few years. It is also likely that the number of Ph.D. degrees will begin to increase in the next year or two.

\section{EMPLOYMENT OR OTHER POST-GRADUATION PLANS}

Data on post-graduation status was not collected in 2005. Comparing the 2006 to the 2004 postgraduation data indicates, in general, a fairly similar distribution in post-graduation plans for each of the degree levels. (See Table 3.) The exception is a higher percentage of the M.S. degree recipients going on to continued study (29\% of those with known plans in 2006 versus $20 \%$ in 2004 ). Continued study is still the largest post-degree activity for the B.S. graduates and medical facility employment continues to be a large employment source for M.S. graduates. As in earlier years, the number of graduates hired by nuclear utilities was still quite small.

In 2006, the employment type "Other Nuclear-Related Employment" was added. Graduates receiving employment in this category in earlier surveys would have most likely been reported in the "Other Business Employment" category. In 2006, it appears that the number of M.S. graduates accepting employment in the "Other Nuclear-Related Employment" category increased somewhat.

Table 3. Employment or Other Post-Graduation Plans, 2006

Continued Study

Academic Employment

Federal Government Employment

DOE Contractor Employment

State and Local Government Employment

Medical Facility Employment

Nuclear Utility Employment

Other Nuclear-Related Employment

Other Business Employment

Foreign (non-U.S.) Employment

U.S. Military, active duty

Other Employment

Still Seeking Employment

Not reported

Totals

\begin{tabular}{ccc}
$\begin{array}{c}\text { B.S. } \\
\text { degree }\end{array}$ & $\begin{array}{c}\text { M.S. } \\
\text { degree }\end{array}$ & $\begin{array}{c}\text { Ph.D. } \\
\text { degree }\end{array}$ \\
\hline 24 & 22 & 2 \\
2 & 4 & 2 \\
2 & 8 & 0 \\
0 & 5 & 0 \\
2 & 1 & 0 \\
4 & 17 & 3 \\
1 & 3 & 0 \\
2 & 6 & 2 \\
2 & 2 & 0 \\
0 & 1 & 1 \\
4 & 4 & 1 \\
0 & 0 & 0 \\
1 & 3 & 1 \\
27 & 14 & 0 \\
\hline 71 & 90 & 12
\end{tabular}


Table 4. Health Physics Degrees, 2006, by Academic Institution

(alphabetical by state and then university)

\begin{tabular}{|c|c|c|c|c|}
\hline \multirow[b]{2}{*}{ State } & \multirow[b]{2}{*}{ Name of Institution } & \multicolumn{3}{|c|}{$\begin{array}{c}\text { Degrees, } \\
\text { Sept. 1, } 2005 \text { - Aug. 31, } 2006\end{array}$} \\
\hline & & B.S. & M.S. & Ph.D. \\
\hline CA & San Diego State University & 0 & 6 & 0 \\
\hline $\mathrm{CO}$ & Colorado State University & 0 & 2 & 1 \\
\hline DC & Georgetown University & 0 & 5 & 0 \\
\hline FL & University of Florida & 0 & 3 & 0 \\
\hline GA & Georgia Institute of Technology & 0 & 6 & 0 \\
\hline ID & Idaho State University & 1 & 7 & 0 \\
\hline IL & Illinois Institute of Technology & 0 & 8 & 0 \\
\hline IL & University of Illinois at Urbana-Champaign & 4 & 1 & 0 \\
\hline IN & Purdue University & 26 & 3 & 0 \\
\hline LA & Louisiana State University & 0 & 1 & 0 \\
\hline MA & University of Massachusetts, Lowell & 2 & 9 & 3 \\
\hline MD & Uniformed Services University (new program) & 0 & 0 & 0 \\
\hline ME & University of Maine & 0 & 0 & 0 \\
\hline MI & University of Michigan & 8 & 9 & 3 \\
\hline MO & University of Missouri - Columbia & 0 & 4 & 1 \\
\hline $\mathrm{NJ}$ & Thomas Edison State College & 7 & 0 & 0 \\
\hline NM & University of New Mexico & 0 & 1 & 0 \\
\hline NV & University of Nevada, Las Vegas & 2 & 3 & 0 \\
\hline NY & Rensselaer Polytechnic Institute & 2 & 0 & 0 \\
\hline $\mathrm{OH}$ & Ohio State University & 0 & 1 & 1 \\
\hline $\mathrm{OH}$ & University of Cincinnati & 0 & 5 & 1 \\
\hline OR & Oregon State University & 4 & 7 & 0 \\
\hline PA & Bloomsburg University of Pennsylvania & 1 & 0 & 0 \\
\hline SC & Clemson University & 0 & 3 & 2 \\
\hline SC & Francis Marion University & 2 & 0 & 0 \\
\hline $\mathrm{TN}$ & University of Tennessee & 4 & 0 & 0 \\
\hline $\mathrm{TN}$ & Vanderbilt University & 0 & 1 & 0 \\
\hline $\mathrm{TX}$ & Texas A\&M University & 8 & 5 & 0 \\
\hline $\mathrm{TX}$ & University of Texas & 0 & 0 & 0 \\
\hline WA & Washington State University, Tri-Cities & 0 & 0 & 0 \\
\hline & TOTALS: & 71 & 90 & 12 \\
\hline
\end{tabular}


Prepared by: Analysis and Evaluation Group, Science Education Programs, Oak Ridge Institute for Science and Education, March 2007.

This document was prepared for U.S. Nuclear Regulatory Commission by the Oak Ridge Institute for Science and Education (ORISE) through an interagency agreement with the U.S. Department of Energy (DOE). ORISE is managed by Oak Ridge Associated Universities under DOE contract number DE-AC05-06OR23100.

The Oak Ridge Institute for Science and Education (ORISE) is a U.S. Department of Energy institute focusing on scientific initiatives to research health risks from occupational hazards, assess environmental cleanup, respond to radiation medical emergencies, support national security and emergency preparedness, and educate the next generation of scientists. ORISE is managed by Oak Ridge Associated Universities.

All opinions expressed in this report are the author's and do not necessarily reflect the policies and views of the U.S. Nuclear Regulatory Commission, the U.S. Department of Energy, or the Oak Ridge Institute for Science and Education or any of their employees. Nor does it necessarily reflect the policies and views of the sponsoring institutions of Oak Ridge Associated Universities. 